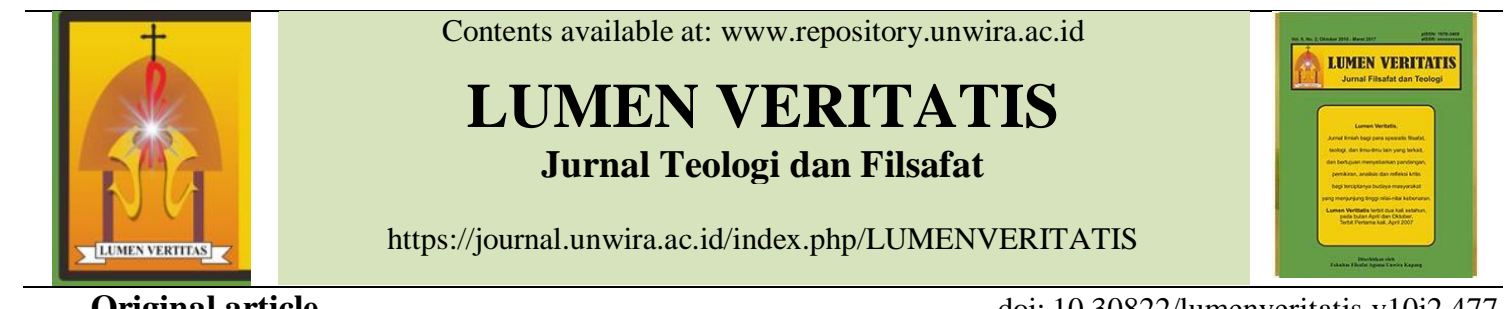

Original article

doi: 10.30822/lumenveritatis.v10i2.477

\title{
PENGUATAN PEMBENTUKAN KARAKTER BERBASIS PERMAINAN BERHITUNG ORANG NGADA
}

\author{
Watu Yohanes Vianey \\ Program Studi Ilmu Filsafat, Fakultas Filsafat, \\ Universitas Katolik Widya Mandira Kupang \\ Email: sigawunga@gmail.com
}

\begin{abstract}
This paper offers the meaning of 'arithmatic game' in local traditions of Ngada. The theory being used is oral tradition theory and modification of diffusion theory neodifusionist who shows the encounter of the spirituality values of muzi sadho from local religion and the 'perfect life' spirituality of the Roman Catholic Church. The nine spirituality hierarchies are found in the meaning of 'arithmetic game' can influence contemporary Ngada people to strengthen the formation of his human character to fight the phenomenon of public outragein the new millennium era.
\end{abstract}

Keywords: Arithmatic game; spirituality; character

\section{Latar Belakang}

Penulis mengawali kajian ini dengan sedikit memperlihatkan beberapa fenomena dunia milenium baru dewasa ini (sejak tahun 2000), terkait dengan tata dunia global yang masih diwarnai oleh beberapa gejala kebiadaban publik yang mempraktikkan tindakan-tindakan yang tidak etis dalam hubungan antar insan dan antar manusia dan lingkungan alam di wilayah publik. Ada praktik fundamentalisme pasar dengan jaringan industri yang materialistis. Ada praktik fundamentalisme agama dengan sikap bigotri seperti yang diperankan oleh ISIS dan agen-agennya dengan luaran jaringan terorisme transnasional. Ada praktik fundamentalisme tubuh dengan kecenderungan manusia yang lebih mementingkan unsur tubuh fisik biologisnya (Ngada: 'tebo lo') dari urusan kejiwaan psikologis (tebo wekiwaka/wera) dan rohani spiritualnya ('mae').

Generasi milenial (yang lahir sejak tahun 1980-an) masih membutuhkan semangat dan sikap hidup yang etis dalam kehidupan sehari-hari, dalam bekerja, berbisnis, beragama, berkeluarga dan bernegara pada abad baru dewasa ini. Semangat dan sikap hidup yang etis itu adalah wujud hidup humanis yang berkemanusiaan yang adil dan beradab. Manakah kristalisasi nilai inti budaya etnik Ngada yang memperlihatkan jatidiri dalam karakter hidup peradabannya? Teori apa saja yang bisa digunakan untuk menelisik masa lalu 
untuk membangun masa depan yang semakin sejati?

Teori yang dipakai untuk alat analisis fenomena budaya dalam konteks kajian ini adalah teori tradisi lisan dan modifikasi teori difusionisme atau neodifusionisme (istilah penulis) yang menekankan peranan sebaran dan serapan kebudayaaan, akibat adanya migrasi manusia dan proses perjumpaan kebudayaan yang inkulturatif dan redemptif. Pertama, teori tradisi lisan. ${ }^{1}$ Perlu disadari bahwa dalam dua dekade terakhir, perhatian terhadap tradisi lisan berbasis 'ingatan' mengalami fenomena "booming" ('the memory boom'), telah menjadi produktif di sebagian besar disiplin akademis dalam humaniora, di wilayah domestik maupun di ranah publik. Kebanyakan komentator melacak teori tradisi lisan berbasis memori sosial ini berasal dengan karya Maurice Halbwachs. Dia mempelopori gagasan bahwa ingatan adalah fenomena sosial yang mendasar. ${ }^{2}$

Jones Sian \& Russel Lynette, Archaeology, Memory and Oral Tradition: An Introduction, Publish Online: Springer Science, Jerman: 2012, hlm. 1-3.

${ }^{2}$ Loc.cit. Setiap komunitas budaya atau komunitas adat mengembangkan ingatan yang menyoroti masa lalunya sendiri dan identitas uniknya. Kerangka sosial ingatan kolektif, dalam tesis Halbwachs, memediasi ingatan individual, dan ada segmen "penutur tradisi" yang kuat dalam kelompok-kelompok sosial itu yang menentukan apa yang mudah diingat dan bagaimana hal itu akan diingat. Namun di sini ada risiko bahwa narasi dominan yang dihasilkan melalui institusi elit tradisi itu biasanya menentukan memori pribadi dari generasi
Kedua, modifikasi teori difusi atau neodifusionisme. ${ }^{3}$ Teori persebaran budaya dalam konteks tulisan ini menegaskan tentang adanya ciri-ciri

mudanya. Dengan demikian, terbuka bahwa memori kolektif dari komunitas adat tertentu, yang dalam tradisi lokal Ngada terhubung dengan komunitas adat level 'kampung' (пиа) level 'suku dan koalisi keluarga berbasis rumah adat' (woe) dan level unit sosial yang paling kecil ( $s a^{\prime} o$ ) tentang masa silamnya, dapat terkait dengan fenomena romantisasi tradisi sendiri yang menegaskan kehebatan identitas mereka dari kelompok lain dan terbuka untuk dapat mengabaikan originalitasnya.

3 Jegalus Norbert, "Filsafat Kebudayaan", Bahan Kuliah Fakultas Filsafat Unwira, Kupang: 2007, hlm. 32-33. Dalam perpektif kajian budaya, yang saya maksudkan dengan teori neodifusionisme berakar pada modifikasi terhadap tiga aliran yang menekankan peranan difusi kebudayaan. Aliran difusi Inggris dengan tokohnya G. Eliot Smith, William J. Pery berteori tentang peradaban dunia pada umumnya yang tersebar melalui kontak dengan tradisi peradaban yang lebih tua dan maju, khususnya peradaban Mesir (Pan Egyptian). Hal mana khususnya yang terkait dengan ketuaan dan keunggulan peradaban Mesir sebagai peradaban lebih tua dan maju, ditolak oleh aliran difusi Amerika. Bagi para antropolog Amerika, yaitu C. Wissler dan Alfred Croeber menegaskan bahwa peradaban Maya dan Inca di Amerika Tengah berkembang secara mandiri, tidak dipengaruhi oleh peradaban Mesir. Bagi mereka, setiap manusia dan komunitasnya pada dasarnya mempunyai daya kreativitas untuk menciptakan kebudayaan sendiri dan terbuka untuk terjadinya evolusi kebudayaan yang paralel. Selanjutnya aliran ketiga adalah aliran kulturkreis, dengan tokoh Pater Wilhelm Schmidt, SVD. Tokoh ini menekankan kemungkinan adanya evolusi kebudayaan yang paralel dan kecenderungan manusia dan komunitasnya melakukan "peminjaman" praktik dan produk budaya secara kontekstual. Kemungkinan dan batas-batas untuk menyerap praktik baik dan menerima produk dan praktik kultural unggul dari budaya lain melalui proses inkultrasi adalah sesuatu yang mungkin terjadi. 
budaya yang khas yang ada pada suatu "culture area" yang tetap terpelihara dan terbuka untuk ditumbuh kembangkan secara baru, sebagai hasil perjumpaan dengan nilai budaya dari wilayah budaya yang lain. Bentuk hubungan kulturalnya ada yang bersifat simbiotis (internal $\quad-$ eksternal); penetrasis (halus - kasar), langsung maupun tidak langsung; yang dalam dan melaluinya menghasilkan fenomena relasi interkultural yang inkulturatif.

Urgensi dari kajian ini adalah menggali tradisi lisan berbasis memori kolektif yang masih terpelihara dalam sistem sosial permainan dan sistem pengetahuan orang Ngada.

\section{Pentingnya pembentukan karakter generasi milenial}

Isu tentang pentingnya pendidikan karakter bagi generasi milenial di Indonesia pada umumnya dan di Ngada pada khususnya sesungguhnya sangat relevan. Karena kebijakan dari Mentri Pendidikan dan Kebudayaan RI pada rejim Joko Widodo (sejak 2016) adalah peningkatan porsi pendidikan karakter untuk tingkat SMP dan SMA yang mencapai $40 \%,{ }^{4}$ yang terdiri dari pendidikan karakter personal seperti hidup jujur, karakter sosial seperti sikap tanggung jawab, dan karakter kebangsaan seperti sikap bela negara.

\footnotetext{
${ }^{4}$ Kantor Berita Antara/4/11/2016), hlm.1.
}

Hal mana terkait dengan sumber-sumber nilai etika yang berasal dari hatinurani (personal), dari adat istiadat (sosial budaya), dari agama (sosial religius), dari konstitusi negara dan dari PBB (sosial politik).

Secara teoritis, karakter muncul dalam wujud sikap dan perilaku keutamaan hidup, yang secara internal kesadaran normalnya ada dalam spiritualitas (hati nurani) setiap insan. Selanjutnya ia tumbuh dalam keluarga dan komunitas adat, di mana seorang manusia dilahirkan dan dibesarkan. Singkatnya, manusia tidak dapat mengabaikan keluarga dan komunitas adat sebagai konteks tempat dan waktu pembelajaran hidup, di mana seorang manusia dididik untuk tumbuh ke arah kesempurnaan. Dalam tradisi kristiani kotbah Yesus di Bukit yang mengajak umat untuk menumbuh kembangkan spiritualitas itu terungkap dalam tekad untuk meraih hidup sempurna seperti Bapa di Sorga yang sempurna adanya (Mat 5:48).

Gaya dan sikap hidup yang kemudian menjadi karakter itu terbentuk melalui aktivitas sederhana: sejak bangun tidur, mandi, berpakian, sarapan dan seterusnya, sampai si anak siap untuk tidur kembali. Juga pembentukan karakter terjadi melalui aktivitas yang kompleks, seperti orang tua memberi nasihat langsung, tentang perbuatanperbuatan baik dan jahat. Atau mereka melakukan pendidikan itu melalui tindakan nasihat, berceritera, mendongeng, bernyanyi dan sebagainya 
untuk mengungkapkan pikiran, perasaan, dan kehendak yang baik, benar dan indah. Selanjutnya sadar atau tidak, orang tua dan komunitas adatnya juga biasa melatih anak-anaknya untuk bekerja keras dan mengambil keputusan untuk menata hidup. Orang tua memuji anak-anaknya jika mereka taat pada perintah yang baik dan menjauhi larangan-larangan, yang telah disosialisasikan dari satu generasi ke generasi berikutnya, seperti yang diwariskan para leluhur melalui media puisi lisan dan ceritera rakyat.

Secara politis, pentingnya konservasi atau proses pewarisan nilai yang baik ini, sesungguhnya sejalan dengan gerakkan rejim pemerintahan Joko Widodo, yang telah mencanangkan program revolusi mental bagi masyarakat Indonesia. Revolusi mental dirasakan dan diyakini sebagai hal paling urgen dan fundamental di tengah merosotnya praksis hidup yang adil dan beradab di level domestik dan publik di wilayah lokal, regional, nasional dan global.

Paparan pengaruh global dalam kata kunci globalisasi pada umumnya diartikan sebagai sebuah proses perubahan sosial yang berskala mondial (global), yang melintasi batas-batas negara, yang mengintegrasikan dan menghubungkan manusia, masyarakat dan berbagai institusinya, sedemikian rupa dalam dimensi ruang dan waktu yang baru. Hal ini antara lain dihubungkan dengan pesatnya pertumbuhan industri pariwisata, industri pakian, industri pangan dan makanan siap saji, teknologi komunikasi dan transportasi, yang membawa percepatan komunikasi dan informasi ke arah yang semakin canggih. Sadar atau tidak, dewasa ini ekologi kesadaran insani memancarkan imaginasi dunia yang 'semakin kecil', karena jarak-jarak tempuh semakin pendek, dan berbagai peristiwa yang terjadi di belahan benua yang satu, dengan mudah dan serentak diketahui oleh manusia di belahan benua yang lain. Dari perspektif kajian budaya, fenomena tersebut memperlihatkan arus homogenisasi dalam perjalanan budaya dan peradaban manusia.

Sejarah mencatat pula bahwa pada tahun-tahun peralihan dari milenium lama ke milenium baru, sejumlah realitas tragis yang berskala mondial mengguncang dunia. Di beberapa negara berkembang terjadi berbagai tragedi kemanusiaan, dalam berbagai bidang kehidupan sosial, khususnya kehidupan sosial budaya, sosial religius, sosial ekonomi, dan sosial politik. Alfons Taryadi mencatat dalam Jurnal "Iman dan Budaya" sejumlah fakta situasi sosial budaya di Indonesia yang dominan 'rawan' tersebut dalam rumusan berikut. ${ }^{5}$

\footnotetext{
${ }^{5}$ Taryadi, Alfons, "Merespons Situasi Sosial Budaya Di Indonesia Masa Kini" Jurnal Iman dan Budaya, Vol 3, No.1 dan 2; Januari- April 2004. Jakarata: Pusat Studi Iman, Ilmu dan Budaya, hlm. 26-46.
} 
Pertama, negara kita dikategorikan sebagai negara yang sangat korup. Bersama Uganda, Indonesia dicatat sebagai salah satu negara terkorup di dunia. Kedua, kerusakan dan perusakan lingkungan. Ketiga, pelanggaran HAM dan perdagangan manusia yang berlindung di balik kebijakan TKI. Sekitar 24 juta perempuan Indonesia pernah mengalami tindakan kekerasan berat. Sepanjang tahun 2019 ada 109 TKI asal NTT yang dikirim pulang mayatnya dari tempat kerja mereka di luar negri.

Keempat, lemahnya reformasi hukum, peradilan dan pendidikan. Di bidang pendidikan, misalnya: Rumusan dalam amandemen UUD bahwa "pemerintah mengusahakan dan menyelenggarakan satu sistem pendidikan nasional yang meningkatkan keimanan dan ketakwaan serta akhlak mulia dalam rangka mencerdaskan bangsa" menjadi problematis dalam kaitan dengan persoalan intervensi negara dalam kehidupan beragama, pendidikan agama dan kehidupan privat warga negaranya. Ada hegemoni nilai dari agama Islam dalam kebijakan dan praktik pendidikan nasional.

Kelima, hedonisme dan konsumerisme. Keenam, hadirnya fakta kemiskinan dan pengangguran. NKRI pada awal milenium baru adalah salah satu negara pengutang terbesar di dunia, dan dengan penduduk yang 10-30 \%-nya mengalami kemiskinan absolut. Ketujuh, mutu pendidikan rendah. Dari
12 negara di Asia, Indonesia mendapat penilaian dari PERC sebagai negara yang bermutu pendidikan paling rendah. Untuk di Indonesia, NTT mendapat predikat bermutu pendidikan paling rendah dari yang telah rendah tersebut.

Kedelapan, kualitas SDM rendah. Menurut hasil penelitian UNDP tahun 2000, dari 174 negara, Indonesia berada di nomor 109. Singapura (24); Malaysia (61), Filipina (77). Kesembilan, angka penderita sakit mental cenderung tinggi. Kesepuluh, masalah etnisitas, keberagaman, dan penghayatan agama. Sensus tahun 2010, menegaskan bahwa di Indonesia ada 1072 etnik dan subetnik. Ada 15 etnik yang penduduknya di atas 1 juta jiwa. Etnis Jawa 83,8 juta. Dalam percaturan politik isu SARA menjadi isu sensitif dan alasan kekerasan berdasarkan fanatisme agama meningkat pada era reformasi.

Kesebelas, keluarga Indonesia hidup dalam dunia nyata yang ditandai dengan adanya perang, terorisme, kekerasan, budaya tidak menghormati kehidupan; perceraian, hidup bersama tanpa nikah, selingkuh, aborsi, gaya hidup hedonisme - sekularisme - materialisme konsumerisme. Berbagai informasi yang tidak jelas mutunya membanjir melalui media elektronik dan virtual, dan anggota keluarga dapat memilih apa yang disukai, meski belum tentu baik dan benar jika dinilai dari sumber nilai agama. Setiap tahun untuk kota Jakarta saja, rata-rata 52.000 pasangan suami istri bermasalah yang meminta nasihat 
pada Badan Penasihat Pembinaan dan Pelesteraian Perkawinan, dan yang bisa didamaikan hanya $40 \%$, sisanya diakhiri dengan perceraian.

Masalah sosial budaya dan religius yang keduabelas, yang turut dipicu oleh dinamika negatif dari globaliasi adalah masalah jaringan narkoba trasnasional, jaringan fundamentalisme agama transnasional; dan pemujaan tubuh dan ekstase hawa nafsu transnasional. Khususnya nafsu seks dan nafsu belanja barang-barang. Dimensi rahasia, moral dan kesucian seksualitas hilang dalam dinamika hidup sebagian manusia yang jatuh dalam pusaran hawa nafsu itu. Konon, globalisasi pariwisata dan globalisasi informasi melalui cyberporno menyuburkan fenomena disorientasi etis dan tindakan seks bebas, dan bahkan brutalitas pemerkosaan. Muncul gejala antagonisme radikal yang fatal pada sebagian masyarakat global yang tidak menuju ke arah rekonsiliasi dan sintesis moral. Gejala antagonisme itu cenderung ke arah dekonstruksi segala asumsiasumsi moral, termasuk asumsi moral yang bersumber dari agama-agama kanonik dan budaya-budaya lokal Ngada, seperti Pata Dela. ${ }^{6}$

Gerakan revolusi mental berupaya untuk mengembalikan massa rakyat Indonesia kepada sejumlah kode nilai, etika, dan

\footnotetext{
${ }^{6}$ Watu Yohanes Vianey, Pata Dela \& Representasi Citraan Manusia Dari Etnik Ngada, Perspektif Kajian Budaya, Kupang: Gita Kasih, 2010.
}

kode perilaku yang sesuai dengan nilai kebangsaan Indonesia. Nilai, etika yang terpatri dalam sanubari dan dihayati dalam kehidupan bersama pada akhirnya dapat membentuk sebuah peradaban dan karakter bangsa. Inilah sebabnya revolusi mental dilihat sebagai momen membangun peradaban bangsa, dan pembentukan karakter manusia Indonesia, yang pada akhirnya membuat bangsa kita menjadi besar dan dapat bersaing dengan bangsa-bangsa lain di dunia. Urgensi pembentukan karakter bagi generasi milenial di Nusantara pada umumnya dan di Ngada pada khususnya begitu mendesak mengingat terjadinya benturan antar peradaban di tingkat global dan proses pemiskinan di tingkat nasional dan lokal.

Revolusi mental selain hadir dalam kebijakan nasional, terdapat pula dalam arena kebudayaan-kebudayaan lokal. Dalam perspektif kajian budaya, puisi lisan seperti Pata Dela, ceritera rakyat seperti dongeng dan mitologi lokal merupakan salah satu media revolusi mental. Sebagai sebuah media, praktik budaya ini menjadi sarana menyampaikan pesan-pesan moral, etika, nilai, dan adat-istiadat yang dikisahkan dari generasi ke generasi.

Persoalannya adalah adanya diskontinuitas informasi dan formasi akibat kegagapan teknologi informasi dari generasi tua untuk mewarisi kode etik lokal yang memuat nilai moral yang membentuk karakter seseorang. Selanjutnya di sisi yang lain ada 
pengabaian terhadap kearifan lokal dari generasi muda milenial. Secara sederhana moral dalam perspektif Kantian, diartikan sebagai norma yang memuat hak dan kewajiban, termasuk apa yang boleh dan tidak boleh dilakukan, wajib atau tidak wajib dilaksanakan oleh seseorang dan sekelompok orang dalam relasinya dengan sesama dalam sebuah masyarakat. $^{7}$

Singkatnya, menurut versi Kebijakan Nasional Pembangunan Karakter Bangsa 2010-2025, karakter adalah nilai-nilai khas yang terpatri dalam diri dan terejawantahkan dalam prilaku. Karakter secara koheren memancar dari spiritualitas seseorang dari hasil olah hati, olah pikir, olah rasa dan olah karsa seseorang atau sekelompok orang. Karakter merupakan ciri khas seseorang atau sekelompok orang yang mengandung nilai, kemampuan, kapasitas moral dan ketegaran dalam menghadapi kesulitan dan tantangan.

\footnotetext{
${ }^{7}$ Watu

Yohanes

Vianey,"Representantion in the Code of Ethics of the Entity of Woe in the Hamlet of Guru Sina, Ngada, Flores". Proceeding, The First InternationalConference on Humanities and Social Sciences, Universitas Negeri Malang, 2016; hlm. 33-55.
}

\section{Permainan berhitung dan pembentukan karakter orang Ngada}

Permainan Berhitung ini dalam tradisi lokal disebut "Mae Ge". Dalam konteks pembentukan karakter, permainan ini adalah media pendidikan nilai dan menjadi bagian komplementer dari sistem pengetahuan spiritualitas lokal. ${ }^{8}$ Hal mana terungkap pada Tabel 1 berikut.

Tabel .1

Hirarki Nilai Spiritualitas Berdasarkan Tradisi Permainan $G e$

\begin{tabular}{|c|c|c|c|c|}
\hline No & B.Lokal & $\begin{array}{l}\text { B. } \\
\text { Nasional }\end{array}$ & B.Lokal & Bahasa Indonesia \\
\hline 1 & Esa geta & Satu & gera geta & Waspada \\
\hline 2 & Zua gua & Dua & adha gua & $\begin{array}{l}\text { Taat adat dan norma } \\
\text { sopan santun }\end{array}$ \\
\hline 3 & Telu getu & Tiga & getu-getu & Teliti dalam bekerja \\
\hline 4 & $\begin{array}{l}\text { Wutu } \\
\text { gutu }\end{array}$ & Empat & gutu gata & $\begin{array}{l}\text { Kerja sama yang } \\
\text { efisien dan efektif }\end{array}$ \\
\hline 5 & $\begin{array}{l}\text { Lima } \\
\text { gima }\end{array}$ & Lima & $\begin{array}{l}\text { gima } \\
\text { ngima }\end{array}$ & $\begin{array}{l}\text { Harus berbagi rejeki } \\
\text { dengan sesama }\end{array}$ \\
\hline 6 & Wolo Ila & Enam & Ila Wolo & Jadi Diri Sejati \\
\hline 7 & Po Pake & Tujuh & Po Pake & $\begin{array}{l}\text { Belajarlah } \\
\text { Pake" }\end{array}$ \\
\hline 8 & $\begin{array}{l}\text { Wawo } \\
\text { Watu }\end{array}$ & Delapan & Nési & $\begin{array}{l}\text { Melampaui kekerasan } \\
\text { batu }\end{array}$ \\
\hline 9 & $\begin{array}{l}\text { Pegu } \\
\text { Melu }\end{array}$ & Sembilan & $\begin{array}{l}\text { Waka } \\
\text { Meku }\end{array}$ & $\begin{array}{l}\text { Lemah Lembut dan } \\
\text { Rendah Hati }\end{array}$ \\
\hline 10 & $\begin{array}{l}\text { Zeta } \\
\text { Gedha }\end{array}$ & Sepuluh & $\begin{array}{l}\text { Muzi } \\
\text { Sadho }\end{array}$ & $\begin{array}{l}\text { Itulah kesempurnaan } \\
\text { kehidupan }\end{array}$ \\
\hline
\end{tabular}

Sumber: Watu, 2016 a.

Praktik permainan dan nilai permainan ini sudah disosialisasikan oleh almarhum

8 Watu Yohanes Vianey, Tuhan, Manusia dan Sa'o Ngaza, Kajian Filsafat Budaya Rumah Tradisional Orang Ngada Flores, Yogyakarta: Kanisius - LPPM Unwira, hlm. 252-257. 
guru Nikolaus Nono, guru pertama dari kampung Guru Sina (menjadi guru tahun 1954 dan meninggal Mei 2006). Beliau adalah ayah kandung peneliti dan juga menjadi salah satu guru spiritual dan kultural lokal bagi peneliti, sebagai anak dan generasi penerusnya.

Sebagai sistem pengetahuan berhitung dalam konteks tradisi permainan yang memuat unsur pendidikan budi pekerti yang memuat nilai spiritual, perhitungan itu dituturkan dengan rumusan: esa geta, zua gua, dan seterusnya, seperti terungkap dalam tabel di atas. Makna esa geta, ditemukan dalam pembiakan kata "geta" sebagai kata majemuk dalam tradisi bahasa lokal, yaitu "gera geta". Kata "gera geta" dalam kecerdasan personal dan sosial setempat, identik dengan semangat dan sikap hidup waspada. Begitu pula seri perhitungan angka-angka berikutnya yang memuat gradasi sistem nilai spiritualitas atau nilai kemanusiaan yang diperjuangkan.

Nomor satu, dalam kehidupan ini, manusia diajarkan untuk 'gera geta' ('selalu waspada'). Nomor dua, manusia harus 'tahu adat' dan 'tahu norma sopan santun' (adha gua) yang dibuktikan dengan tindakan penegakkan hukum dalam berbagai dimensi kehidupan; nomor tiga, manusia harus 'teliti' baik dalam 'bekerja' maupun dalam 'membedakan roh' (getu-getu); nomor empat, manusia harus dapat terbuka untuk 'kerja sama' secara efisien dan efektif dengan sesama (gutu gata), nomor lima manusia harus 'berbagi rejeki' dengan sesamanya dengan sukacita (gima ngima).

Dengan sungguh-sungguh menenun karakter nomor satu sampai dengan nomor lima, maka manusia akan menjadi manusia nomor enam, yang memiliki jatidiri, yang dalam metafor Pata Dela disebut manusia "ila wolo". Lengkapnya "kéga moe ila wolo" ('kering seperti buluh gunung'). Metafor "kering" mengacu pada kualitas kering yang "sempurna", seperti keringnya buluh pegunungan, yang "tetap setia dalam kekeringannya" walaupun diguyur dan direndam dalam air. Karena itu ia akan tetap dapat menyala dengan baik, jika dibakar dalam api. Dalam tradisi lokal ila wolo itu menjadi media pilihan utama untuk menjadi kayu bakar untuk menghasilkan terang yang prima.

Menjadi 'manusia ila wolo' berarti bertransfigurasi sebagai insan yang setia menjadi tanda sarana bagi memancarnya terang Ilahi yang menetap di dalam dirinya, untuk menerangi sesama dan dunia kehidupan pada umumnya. Maka, menjadi insan "sempurna" dalam nomor yang keenam ini, berarti menjadi insan yang setia sebagai 'terang' bagi sesama sebagai bagian integral dari praksis partisipasi dalam terang Ilahi yang berbasis kasih sejati (Latin: ceratio ex amore) dengan mewujudkan lima prinsip terdahulu, yaitu prinsip gerageta, adha gua, getu-getu, gutu gata, dan gima ngia, secara gradual dan holistik. 
Supaya jatidiri itu terus berproses ke arah yang lebih sempurna lagi, maka manusia dianjurkan untuk belajar "po pake" ('ilmu katak'dan 'ilmu pakai') di nomor tujuh. Manusia diminta untuk belajar dari "katak" yang anti kekerasan dan tahan terhadap "kemarau" kehidupan dengan ilmu 'sabar' (nési) dan 'terus berjuang' (ghuli) menghadapi kompleksitas kehidupan, seraya tetap terbuka untuk berharap dan peka bersyukur terhadap "hujan kehidupan" (rejeki) dari langit, sebagai ekspresi sikap iman, harapan, cinta kepada sang Dewa Saga Telu dengan menggunakan'ilmu katak' yang diwujudkan dalam tindakan konkret ('ilmu pakai'). Diksi atau pilihan kata untuk ekspresi iman dan harapan yang diwujudkan ini, dalam tradisi lokal terungkap dalam kata majemuk aghuaghu.

Untuk sanggup "nesi, ghuli, dan aghuaghu", orang (atta) perlu berjuang memperindah terus menerus isi hatinya (atte), dengan naik ke nomor delapan, yaitu mengolah hatinya dari hati yang keras kasar seperti batu, menjadi hati yang 'melampaui kekerasan dan kekasaran batu' (tolo watu). Hasilnya adalah hatinya memuat kehalusan dan kelembutan 'nurani' (nuatte) dan kekuatan kesadarannya meningkat dari level be'o bida (cerdas mengenal) ke level dhiji jena (cerah jelas).

Setelah berhasil meraih kualitas pribadi nomor kedelapan, manusia diajak untuk berani naik ke nomor sembilan, tanpa mengabaikan nomor-nomor sebelumnya dengan mengolah semangat dan sikap hidup pegu melu, yaitu semangat dan sikap hidup lemah lembut dan rendah hati yang menghasilkan waka meku ('kejiwaan yang berciri lemah lembut dan rendah hati'). Melalui internalisasi dan aktualisasi semangat dan sikap hidup lemah lembut dan rendah hati itulah, manusia akan naik ke tingkat kesepuluh untuk muzi sadho, yaitu 'hidup baru' (muzi) yang 'sempurna' (sadho).

Maka melalui rangkaian olah 'jiwa-roh' yang serius dari nomor satu hingga ke nomor sembilan, manusia akan berproses menjadi 'manusia baru' dan 'baru menjadi 'manusia sempurna' yang menggapai tujuannya yang ultim dan transendental, yaitu "muzi sadho". Kata "sadho" adalah serapan bahasa Sansekerta dari akar kata "sadh -a/o/u" = mencapai tujuan, mencapai kesempurnaan. Usaha untuk mencapai kesempurnaan disebut "sadhana", dan orang yang berusaha mencapai tahap kesempurnaan itu disebut "sadhu".9 Istilah "sadhu" diserap ke dalam bahasa lokal dalam kata "sadu" yang berarti "benar, cocok, serasi". Jadi manusia sadho dalam konteks sistem perhitunganmasyarakat setempatadalah paralel dengan citra manusia yang "sempurna", yang sadu, yaitu manusia

9. I Gde Semadi, dkk., Kamus Sanskerta Indonesia, Denpasar: Milik Pemerintah Provinsi Bali, 2000; hlm 512 
yang benar, manusia yang cocok, dan manusia yang serasi, baik sebagai makhluk pribadi, makhluk sosial, maupun sebagai makhluk religius. Dalam ungkapan Pata Dela, pencitraan "muzi sadho" itu dianalogikan dengan keberadaan insani yang sampai di puncak gunung kehidupannya, yaitu "sadho Ine Rie, leba Suru Laki. Gunung tertinggi di wilayah ini adalah gunung Ine Rie Rokka (2245 m) dan gunung Suru Laki atau Ebu Lobo (2.149 m) yang berada di wilayah Nage Keo. Jadi sadho Ine Rie berarti sampai 'di puncak'(gedha) gunung Ine Rie, dan leba Suru Laki berarti 'melampaui puncak' (leba) gunung Suru Laki. Juga disebut Sadho Dala Ko Leba Ringa Wula, (sampai di 'jaringan bintangbintang dan melampaui perapian bulan'. Jadi dalam konteks sistem pengetahuan berhitung dalam budaya ini, spiritualitas manusia yang diperhitungkan sebagai manusia yang muzisadho adalah paralel dengan spiritualitas manusia yang melampaui nilai sembilan atau di atas nilai sembilan, karenanya ia bernilai sepuluh. Kesempurnaan tersebut sesungguhnya berpusat pada pengolahan dimensi bathinnya atau dimensi spiritualnya yang terbuka terhadap dimensi sakralitas dan moralitas secara gradual, yang berjalan sepanjang 9 (sembilan) tahap, yang berawal dari gaya hidup gera geta ('waspada') dan berakhir pada gaya hidup pegu melu ('lemah lembut dan rendah hati').
Dalam rumusan yang berbeda dengan makna yang relatif sama, manusia muzisadho ini sesungguhnya adalah manusia yang setia berjuang memantulkan citra Tuhan (nenu ngia Dewa) dari kebeningan bathin sendiri, yang sejak awal mula dalam kuasa Roh Kudus (Ngaru Santo/Dewa Ja'o/Dewa One Atte Ja'o), telah menetap di dalam kedalaman lubuk hati jatidirinya (bdk. 1 Kor 3: 16; Rom 5: 5; Rom 8: 26). Kelak, sesudah kematian 'tubuh'-nya (tebo lo), melalui kebajikan vertikal dan horisontal yang dilakukannya selama hidup di dunia fana ini, manusia muzisadho itu berharap meraih kebahagiaan abadi dengan bertransfigurasi menjadi Riwu Dewa dalam hadirat Dewa Saga Telu, yaitu Dewa Zeta Wawo dan Dewa One Sa'o dan Dewa One Ate Ja'o. ${ }^{10}$

Seperti apakah citraan konkret manusia yang mencapai derajat 'sempurna' itu? Dalam tradisi lokal citraan konkret itu baru dapat dievaluasi dan ditentukan setelah seseorang meninggal dunia. Melalui evaluasi kritis terhadap perjalanan hidupnya dan diteguhkan dengan divinasi Tibo Dhi'o, maka baru diketahui derajat kesempurnaan hidup seseorang. Jika seseorang oleh komunitas Sa'o Ngazanya, dikuburkan dengan ritus penguburan Gore Gote, maka itulah tandanya, bahwa orang tersebut masuk

\footnotetext{
${ }^{10}$ Watu Yohanes Vianey, Tuhan, Manusia dan Sa'o Ngaza, Kajian Filsafat Budaya Rumah Tradisional Orang Ngada Flores, Yogyakarta: Kanisius - LPPM Unwira, hlm. 279-286.
} 
dalam kategori hidup sempurna (muzisadho) dalam pengolahan kehidupan spiritualnya.

Ada tiga jenis ritus penguburan dalam tradisi lokal. (1) Ritus penguburan Mata Ade. Ritus penguburan biasa, karena derajat kesempurnaan orang tersebut termasuk dalam kategori biasa-biasa, dosa dan kebaikannya relatif seimbang. (2) Ritus penguburan Mata Golo. Ritus penguburan bagi orang yang mati karena kecelakaan atau pembunuhan. Dalam pandangan lokal orang yang mati seperti ini adalah orang yang relatif 'berdosa' atau yang menanggung 'akibat dosa' dari kerabatnya. Dia mati karena ada unsur kesalahan yang berat yang pernah dibuatnya atau dibuat oleh komunitas terdekatnya sampai pada level generasi ke-5. (3) Ritus penguburan Gore Gote. Inilah ritus penguburan bagi orang yang muzi sadho. Kematiannya tidak boleh ditangisi tetapi harus dirayakan. Karena kematiannya adalah pintu menuju kesempurnaan hidup abadi bersama Riwu Dewa dalam lingkaran hadirat akhiri Ilahi. Peneliti pernah mengikuti ritus Gore Gote ini pada tahun 1977. Pada saat penguburan almarhum Petrus Gale No'u. Beliau adalah Dela dari Woe Ago Ka'e, dari Sa'o Pu'u Manu Milo.

Dalam konteks dinamika budaya global, dalam terang refleksi Joe Holland ${ }^{11}$ sebetulnya manusia dewasa ini

${ }^{11}$ Holland, Joe., "A Postmodern Vision Spirituality and Sociaty", dalam Griffin, David R., (ed) Spirituality and Sociaty Postmodern sungguh mengalami krisis spiritualitas. Esensi krisis spiritualitas itu adalah bahwa energi-energi kreatif bathiniah manusia sebagai anugerah Ilahi, yang membuatnya menjadi co-creator ('rekan Pencipta') yang secitra dengan diri-Nya, dalam proses menata kehidupan bathin dan sosialnya, sedang disesatkan menuju kehancuran. Kehancuran yang dimaksudkannya adalah terjadinya antagonisme nilai spiritualitas antara spiritualiatas tradisional, yang bersumber dari nilai-nilai tradisional yang diwariskan oleh tradisi-tradisi agama besar dan tradisi-tradisi religi lokal, relatif lemah dihayati oleh para penganutnya, karena kalah dan bahkan sudah terlanjur sekarat dan bahkan ada yang sudah mati, tatkala berjumpa dan berlawanan dengan tawaran sekularisme dan materialisme global.

Sekularisme dan materialisme global itu memilih memuja uang atau Mamon (bdk. Mat 6:24), dan merayakan hasrathasrat, dengan prinsip, seperti 'dipompakan' oleh kaum Nietzchenian ortodoks: Amor fati et carpe diem! ('cintailah nasibmu dan nikmatilah hari ini'). Karena bagi mereka, tak ada yang diinginkan manusia selain ethos yang hedonistis itu, yang merayakan hasrathasratnya pada masa sekarang dan di sini, tidak di masa depan, tidak di masa lalu, tak pula pada keabadian. Pemujaan terhadap Mamon itu, dalam kearifan lokal, berkaitan erat dengan pemuasan

Vision, USA: State University Press, hlm. 41-42 
'mesin' hasrat-hasrat rendah, yang menyeruak dari kegelapan, keliaran, dan kebuasan dimensi wéra. Sesuatu yang harus dikendalikan dengan canggih seumur hidup, dengan terus menerus merevitalisasi nilai spiritualitas dari 'rumah' kita sendiri, yang terjalin erat dengan dimensi sakralitas dan moralitas komunitariannya.

\section{Kesimpulan}

MaeGe layak menjadi cerminan nilainilai masa lampau yang adiluhung dari akar kultural orang Ngada, yang melalui penggunaan dan penghidupannya setiap saat, dapat mempertahankan kehidupan dan kelangsungan nilai kemanusiaan yang etis, yang dimuliakannya. Ia menjadi suatu bentuk ekspresi, konsentrasi rasa, dan pemikiran dari leluhur berdasarkan pengalaman hidup konkret.

Produk budaya lokal di atas pekat dan padat, tetapi sederhana dan indah, yang mengungkapkan filsafat hidup. Filsafat hidup yang memuat moralitas dan spiritualitas itu sungguh memberi inspirasi dan motivasi peradaban hidup bermoral atau beretika yang berbasis pada prinsip kepedulian pada sesama.

Maka untuk memaksimalkan manfaat permainan dan makna spiritualitas $G e$ untuk pembentukan karakter, perlu dikampanyekan moral kepedulian bagi sesama, yang dalam bahasa lokal prinsip moral kepedulian itu disebut prinsip mesu mora ('kasih cinta'). Dalam dan melaluinya sekurang-kurangnya manusia mewujudkan keharusan untuk wagha mogha ne'e padhi loka ('ambil dan berbagi dengan tetangga'), serta menghidupkan keutamaan modhe ne'e soga woe - meku ne'e doa delu ('berbuat baik sebagai teman - berlembut hati sebagai sahabat'). Itulah karakter dan rahasia hidup la'a netu zala, page nono wesa (hidup yang 'berjalan sesuai aturan, berlangkah sesuai rencana'). Dengan demikian Anda akan dapat meraih derajat spiritualitas tertinggi dalam tradisi Ngada, yaitu karakter dan spiritualitas nomor sembilan dalam permainan $G e$, yaitu karakter dan spiritualitas 'pegu melu' dalam artinya yang otentik, yaitu karakter dan spiritualitas lemah-lembut dan rendah hati yang juga diamanatkan oleh Yesus Kristus bagi para murid dan sahabat-Nya (Mat 11:29) untuk meraih derajat kesempurnaan (muzisadho), seperti Bapa yang sempurna adanya (Mat 5:48).

\section{Daftar referensi}

Anonim, 1973. Alkitab, Ende: Nusa Indah

Barker, Chris, 2005. Cultural Studies, Teori dan Praktik, Yogyakarta: Bentang.

Barnes, R.H., 1972. "Ngada", dalam LeBar, Frank M. (ed.), 1972. Ethnic groups of insular Southeast Asia; Andaman Islands and Madagaskar, New 
Haven: Human Relation Area Files Press.

Bellwood, Peter, 2000. Prasejarah Kepulauan Indo-Malaysia, Jakarta: Gramedia.

Christomy, T., dan Untung Yuwono (penyunting), 2004. Semiotika Budaya, Jakarta: Pusat Penelitian Kemasyarakatan dan Budaya Direktorat Riset dan Pengabdian Masyarakat Universitas Indonesia.

Cobb, John B., 1990. Two Types of Postmodernism: Deconstruction and Process" Theology Today 47: 149158.

Copelston, Frederich, 1974. A History of Philosophy, New York: Dobleday.

Djawanai, St., 1983. Ngadha Text Tradition, Canberra: ANU Printing Service.

Ford, S.Lewis, 1984. The Emergence of Whitehead's Metaphysics, Alabny: State University of New York Press.

Giddens, Anthony, 2003. Masyarakat Pos-Tradisional, (terj.) Ali Noer Zaman, Yogyakarta: RCiSod.

Haedar, Nashir, 1999. Agama dan Krisis Manusia Modern, Yogyakarta: Pustaka Pelajar.

Heriyanto, Husain. 2003. Paradigma Holistik, Dialog Filsafat, Sains, dan Kehidupan Menurut Shadra dan Whitehead, Jakarta: Teraju.
Holand, Joe,

Jones Sian \& Russel Lynette, 2012, Archaeology, Memory andOral Tradition: An

Introduction, Publish Online:

Springer Science.

Kristina, Bebhe. 2016. 'Menelusuri Makna Filosofi Arsitektur Vernakular Pada Perkampungan Tradisional Gurusina'. In Menelusuri Arsitektur Vernakular NTT Seri 2, edited by Reginaldo Christophori Lake, 67-98. Padang: rumahkayu.

Lake, Reginaldo Christophori. 2015. Wologai, Eksotisme Vernakular Di Kaki Gunung Lepembusu. Kupang: Gita Kasih.

LeBar, Frank M. (ed.), 1972. Ethnic groups of insular Southeast Asia; Andaman Islands and Madagaskar, New Haven: Human Relation Area Files Press.

Leenhouwers, 1988. Manusia Dalam Lingkungannya. Refleksi Filsafat tentang Manusia, Jakarta: Gramedia.

Magnis-suseno, $\quad$ Frans,SJ., 1993. Filsafat Sebagai Ilmu Kritis, Yogyakarta: Kanisius.

McIntyre, Alasdair, 1981. After Virtue. A Study in Moral Theory, London: Ducworth. 
Molnar, Andrea Katalin, 1994. Vatikan II, 1993. Dokumen-Dokumen Grandchildren of the Ga'e Ancestors, Konsili Vatikan II, (terj.) R. Social Organisation and Cosmology Hardawirjana, Jakarta: KWI- Obor. among the Hoga Sara of Flores, Leiden: KITLV Press.

Nakamura, Hajime, 1978. Ways of Thinking of Eastern Peoples, Honolulu: Hawaii University Press.

Ritzer, George, 2004. Teori Sosial Postmodern, (terj.) Muhamad Taufik, Yogyakarta: Kreasi Wacana.

Robinson, Fiona,1999. Globalizing Care. Ethics, Feminist Theory, and International Relation, Boulder: Westview Press.

Smedal, H. Olaf, 1996. "Conquest and Comfort A Ngadha Bad Death Ritual", dalam Signe Howel (ed) For The Sake of Our Future Sacrificing In EasternIndonesia, Leiden: Research School CNW, Vol 42. , 2000. "The Aesthetic of Ngadha Houses", Anthropology and Aesthetics, 37, Spring.

Sugiharto, Bambang I., 1996. Watu, Yohanes Vianey, 2010. Pata Dela \& Representasi Citraan Manusia Dari Etnik Ngada, Perspektif Kajian Budaya, Kupang: Gita Kasih.

2013. RepresentasiKode Etik Orang Ngada, Kajian Dari Kampung Adat

GuruSina, Kupang: Gita Kasih. 2016 a. Tuhan, Manusia dan Sa'o Ngaza, Kajian Filsafat Budaya Rumah

Tradisional Orang Ngada Flores, Yogyakarta: Kanisius - LPPM Unwira

2016 b. "Representantion in the Code of Ethics of the Entity of Woe in the

Hamlet of Guru Sina, Ngada, Flores". Proceeding, The First International Conference on Humanities and Social Sciences, Universitas Negeri Malang.

Postmodernisme Tantangan Bagi

Filsafat, Yogyakarta: Kanisius

Sutrisno, Mudji dan Hendar Putranto, 2005. Teori-Teori Kebudayaan, Yogyakarta: Kanisius.

Turner, Brian S, 1991. Religon and Social Theory, London: Age Publication Ltd. 


\section{Riwayat singkat Penulis}

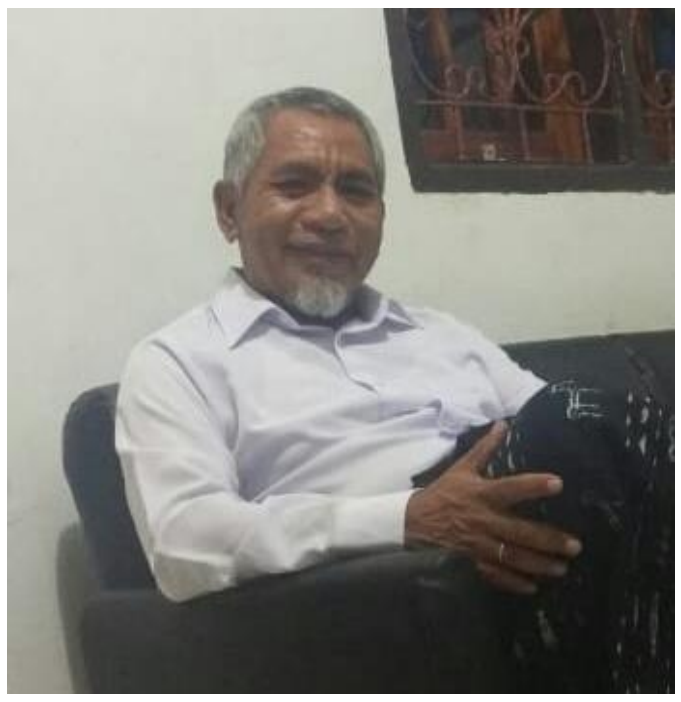

Watu Yohanes Vianey lahir di RutoNgada, 8 Agustus 1962. Saat ini bekerja sebagai dosen Universitas Katolik Widya Mandira Kupang, dengan jabatan akademik Lektor Kepalapada Mata Kuliah: Penelitian Kebudayaan, Etika, dan Agama pada Fakultas Filsafat dan pada beberapa Fakultas lain di lingkungan akademik Universitasnya di jenjang S1 dan S2. Sebagai dosen luar biasa dia mengajar di Program Pascasarjana STAKEN Kupang.

Secara struktural Watu menjabat sebagai Kepala Divisi Penelitian pada LPPM Universitas Katolik Widya Mandira, Kupang, NTT (2015) dan Kepala LPPM (2018). Penulis adalah sarjana filsafat dari STFK Ledalero, Maumere-Flores (1986), magíster theologi dan humaniora dari Universitas Sanata Dharma, Kentungan-Yogyakarta (2001), dan doktor kajian budaya dari Universitas Udayana, Denpasar (2008).
Beberapa buku yang pernah ditulisnya adalah "Sastra Lisan Orang Ngada di Bajawa (1998), Seruan Kepada Sang Manusia Yang Menjadi Tubuh Dalam Sejarah, Saduran Puisi Karol Woijtila - Sri Paus Yohanes Paulus II (2002), Meditasi-KontemplasiAdorasi Kuasa YHWH Sabaoth (2009). Pata Dela \& Representasi Citraan Manusia Ngada, Perspektif Kajian Budaya (2010); Kode Etik Orang Ngada, Kajian Dari Kampung Adat Guru Sina (2013), Tuhan, Manusia, dan Sa'o Ngaza, Kajian Filsafat Budaya Rumah Tradisional Orang Ngada (2016), Pandangan Ketiga Tentang Yesus (2019), .Dr. Agustinus Tri Edy Warsono, Pr

Alumnus Universitas Kepausan Lateran, Roma

Pengajar Hukum Gereja di Fakultas Teologi

Universitas Sanata Dharma, Yogyakarta 